\title{
DACHAU E O (NÃO) PERTENCIMENTO
}

Luís Roberto Amabile é mestre em Teoria da Literatura/ Escrita Criativa pela PUCRS e doutorando na mesma instituição. É autor do livro de contos $O$ amor é um lugar estranho (Grua Livros, 2012). Mantém o blog http://moltoamabile.blogspot.com.br/. E-mail: luisrobertoamabile@gmail.com.

E desde os primeiros dias, no entanto, parecianos impossivel preencher a distância que descobrimos entre a linguagem de que dispúnhamos e essa experiência que, em sua maior parte, nos ocupávamos ainda em perceber nos nossos corpos.

Feito animais rumo ao abatedouro, eles são trazidos em comboios. Procedem de todos os lugares. Caminham em silêncio e com alguma dificuldade no chão forrado de pedras. A princípio não entendem. Seus passos se firmam, mas se perdem. Eles também. Fragmentam-se. Esse lugar existe? É possível?, e os pensamentos acompanhados de pontos de interrogação funcionam como um escudo. Mas a consciência não se tranqüiliza e, por um instante, no meio do pátio do campo de concentração da cidade de Dachau, na Alemanha, todos parecem esquecer a condição de turistas.

Em 22 de março de 1933, apenas algumas semanas após Adolf Hitler ter sido nomeado chanceler, o primeiro dos campos de concentração nazistas foi erguido. O lugar escolhido foi uma fábrica de munição abandonada, num município a $18 \mathrm{~km}$ de Munique, capital da região da Baviera. De início, Dachau era destinado aos prisioneiros políticos, mas com o avanço do nazismo se tornou um depósito para judeus e outras minorias escarradas por Hitler. Além de servir de cenário para experiências médicas que usavam os prisioneiros como cobaias. Usando uma expressão do folheto explicativo à venda no local, Dachau foi uma "escola da violência".

Eles quiseram fazer de nós animais, obrigandonos a vier em condições que ninguém, digo bem, ninguém, poderá jamais imaginar. Mas eles não vão conseguir. Porque nós sabemos de onde viemos, sabemos porque estamos aqui.

Mesmo após todos os filmes assistidos, descrições lidas e fotos vistas, a experiência de ver in loco um campo de concentração, repetir o trajeto dos prisioneiros quando chegavam e, sobretudo, imaginar como era o dia-a-dia ali é algo que ficará a doer na memória por bastante tempo.

A começar pela arquitetura funcional, passando por torturas, jornadas de 11 horas trabalhos forçados, alimentação insuficiente

...os poucos pedaços de batatas ficam no fundo; após ter bebido o líquido, esperamos um instante, olhamos o montículo de batatas no fundo da gamela e depois o atacamos. Depois sobra apenas o fundo da gamela, o metal que raspamos e que ressoa.) 
e falta de condições básicas de higiene,

Um telheiro cobria a fossa, não o mictório. Atrás de nós, barulho de tamancos, tosses outros chegavam. As latrinas nunca ficavam vazias. O tempo todo pairava um vapor sobre os

mictórios.

Dachau serviu de modelo para todos os outros campos de concentração - e chegaram a ser 32 - até o fim da guerra. Foram encarceradas cerca de 200 mil pessoas de 1933 até o final da $2^{\text {a }}$ Guerra (1939-45). Logo após sua liberação, por soldados norteamericanos, em 29 de abril de 1945, o campo de concentração foi parcialmente demolido. Porém, em 1965, sob os auspícios do governo de Baviera e de grupos de sobreviventes, o local foi transformado no Memorial do Campo de Concentração de Dachau. Para que isso fosse possível, algumas partes foram até reconstruídas. Hoje recebe cerca de 800 mil turistas por ano.

\section{Como nos resignar a não tentar explicar como havíamos chegado lá? Nós ainda estávamos lá. \\ E, no entanto, era impossivel. Mal começávamos a contar e sufocávamos.}

O impacto da visita começa antes mesmo da entrada, quando se avista as sete torres de vigília e os altos muros encimados com arame farpado. O roteiro mais indicado começa pelo museu no edifício central, que originalmente abrigava cozinha, lavanderia, armazéns e sala de torturas. Ali há uma exposição permanente que contextualiza o visitante. Narram-se os antecedentes da chegada de Hitler ao poder, explica-se a perseguição dos judeus e contase a história dos campos de concentrações. Além disso, estão expostos 800 artigos originais do período nazista, como jornais com a propaganda do regime e registros de prisioneiros.

Após o museu, pode-se visitar o que restou do que era o refeitório, as celas e os crematórios. Em outro edifício, ficam os alojamentos, que foram reconstruídos nos moldes originais. Também se pode entrar nas câmaras de gás disfarçadas de chuveiros coletivos, para o extermínio em massa. As câmaras de Dachau, entretanto, nunca chegaram a ser usadas. Por algum motivo, não houve tempo para fazer a ligação do gás. Isso não impediu que 43 mil prisioneiros - quase um quarto do total - ali morressem. O escritor francês Robert Antelme chegou muito perto de ser um deles.

Quase irreconhecível, foi resgatado por amigos (um deles teria sido o futuro presidente francês François Mitterrand) em meio a um amontoado de corpos que jaziam no pátio central de Dachau após a expulsão dos nazistas. Era membro da Resistência e em junho de 1944 foi preso pela Gestado e passou por outros campos de concentração antes de ser encarcerado em Dachau. Antelme narrou sua experiência no hoje clássico $A$ espécie humana, publicado em 1957. As epígrafes pertencem ao livro.

Tudo se passa como se pertencer à espécie humana não fosse garantido, como se fosse possivel nela entrar e sair; nela estar apenas parcialmente ou a ela pertencer plenamente ou jamais pertencer. 